\title{
METAFORMOSIS PEMIKIRAN INTELEKTUAL MUDA NU: Suatu Pandangan dari Outsider NU
}

\author{
Oleh: Kamaruzzaman Bustamam-Ahmad .
}

\section{Abstract}

This paper tries to elaborate how the role of youth of NU in Indonesia Islamic thought. The main focus of this paper is the intellectual tradition young generation of NU. The 2000s constitute the years where the youth of NU stay in every where and influenced the life of Indonesia intellectuality. The writer argues that there are some factors in the genealogy of their thought: First, Islamic boarding school as the central of intellectual tradition of NU; Second, the NGO's working; Three, the scientific networking from Egypt. Four, The State Institute of Islamic Studies (IAIN) as the place that did not make their intellectual satisfactory. They look for the other activity; Five, the influence of contemporary Islamic thought whose tends radically and left; Six, the relation with the Indonesians; Seven, the figure of Gus Dur as the protector for them in their liberal idea.

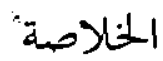

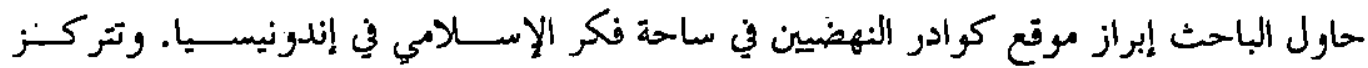

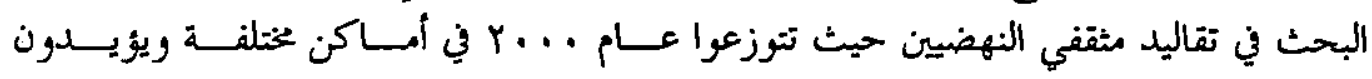

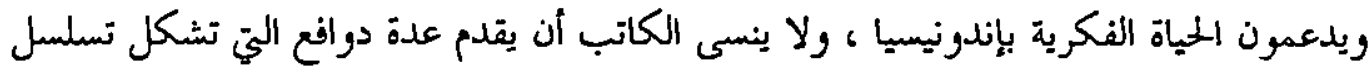

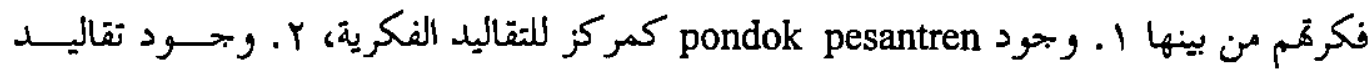

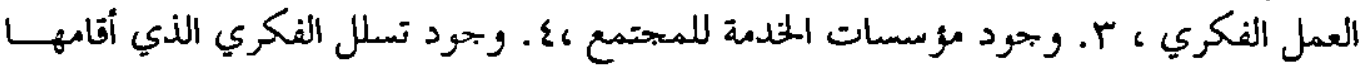

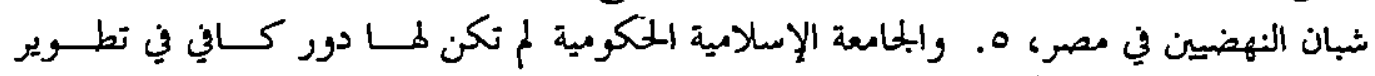

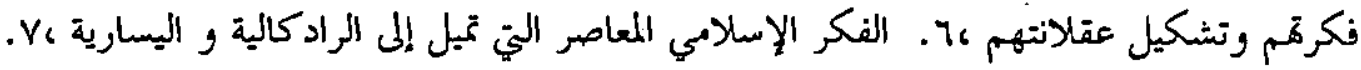

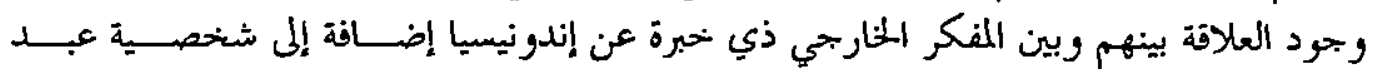

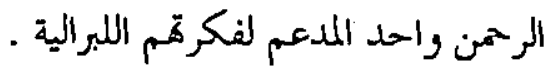

Kata Kunci: Intelektual Muda NU, Pesantren, LSM, Indonesianis

- Mahasiswa S-2 University of Malaya, Kuala Lumpur, Konsentrasi Politik Islam di Asia Tenggara. 


\section{A. Pendahuluan}

Jadi, nasihat yang baik buat orang-orang NU barangkali dengan mengatakan, "Diamlah kalian, karena kalian kalah pintar dari yang lain. Kalau kalian 'marah', orang-orang pintar akan 'memluntir' kemarahan kalian untuk 'membodohbodohkan' kalian. Jangan berbuat kerusakan, karena orang-orang pintar akan 'mengutuk' kalian sebagai tidak tahu demokrasi. Belajarlah pada orang-orang pintar di kota itu; mereka berbuat 'kerusakan' secara 'beradab' dan licin, tetapi mereka dipuji semua orang. Kalau kalian sudah bisa berbuat kerusakan secara 'beradab; seperti mereka, barulah kalian boleh ikut main. Jangan lupa itulah aturan mainnya. ${ }^{1}$

Ada apa hingga Ulil begitu "marah" ketika mengulas kemarahan warga NU ketika “dipecundangi"selama Era Reformasi? Apakah selama ini, dia memandang NU memang sering dijadikan kucing kurap dalam konstelasi politik Indonesia. Apakah Ulil tidak bisa memahami sirkulasi politik Indonesia yang kadang kala sering menguntungkan NU atau sebaliknya. Kenapa dia punya sedemikian kata-kata sarkasme untukmenunjukkan bahwa $\mathrm{NU}$ memang sering dikerjain dalam kancah politik Indonesia.

Artikel ini memang tidak bermaksud membahas bagaimana orang NU sering marah yang kerap ditumpah dalam tulisan ataupun aksi pengrusakan. Demikian juga, kajian ini bukan ingin membuka selimut politik NU yang sering mengusung $k$ hittah-nya. ${ }^{2}$ Esai ini hanya hendak mengungkapkan bagaimana anak-anak muda NU (seperti Ulil ) dalam kancah pemikiran Islam di Indonesia. Dengan kata lain, fokus utama kajian ini memang akan menilik sekaligus melirik tradisi intelektual generasi muda NU.

Sebab, pada tahun 2000-an ini, ada tahun-tahun dimana anak muda NU meminjam istilah AriefBudiman - menjadi "bintang lapangan." Mereka ada dimanamana, sehingga warna anak muda NU sedemikian kental dalam kehidupan intelektual Indonesia. Hampir setiap hari, tulisan mereka dipublikasikan di media massa, suara mereka didengar dalam seminar, penelitian mereka didanai oleh funding-funding internasional. Karena itu, anak-anak muda NU seolah-olah bak seorang bayi yang sedang "nakalnakalnya" atau remaja yang sedang menginjak masa "puberitas" dimana semua yang mereka lakukan harus "dipahami" bukan "dilarang."Mereka bahkan tidak mau "diawasi," karena itu, mereka ingin kebebasan (baca: liberal) baik dalam pemikiran maupun tingkah laku. Dalam tulisan ini, anak muda NU atau intelektual muda NU yang saya maksudkan

'Ulil Abshar-Abdalla, 2002, "Orang NU Dibodohi, Pintarnya Orang Lain," dalam Bahrul "Ulum, "Bodohnya NU" apa "NU Dibodohi"?, Yogyakarta: Ar-Ruzz, hal. 31.

${ }^{2}$ Lihat Martin Van Bruinessen, 1997, "Konjungtur Sosial Politik di Jagat NU Paska Khittah 1926: Pergulatan NU Dekade 90-an," dalam Ellyasa KH Dharwis (ed.), Gus Dur, NUdan Masyarakat Sipil, Yogyakarta: LKiS, hal. 61-86. 
adalah mereka yang berasal dari NU, baik secara personal maupun kelembagaan. ${ }^{3}$

\section{B. Geneologi Pemikiran Intelektual Muda NU}

Barangkali, satu-satunya kajian organisasi Islam yang mendapat perhatian serius para sarjana adalah NU (Nahdhatul 'Ulama). Sejauh ini, karya yang mengupas tentang NU sangat banyak, baik yang ditulis oleh para sarjana Indonesia maupun luar negeri. Namun demikian, kajian yang melacak akar geneologi intelektual muda era 2000-an memang sangat sulit dijumpai. Namun demikian, posisi generasi muda ini memang sangat unik, sebab basis intelektual mereka memang bukan melalui jenjang akademik murni. Hampir semua mereka adalah lulusan S-1 atau sedang menempuh S-2. Namun, pikiranpikiran mereka telah "meloncat" melebihi professor sekalipun. Tidak jarang pikiran mereka menjadi basis dalam menganalis suatu pemikiran yang berkembang di Indonesia. ${ }^{4}$

Paling tidak, pemikiran anak muda NU memang lebih banyak berkutat di beberapa kota saja, yaitu Jakarta, Yogyakarta, Surabaya, dan kota-kota kecilnya. Namun demikin, tiga kota pertama memang telah menjadi tempat anak muda NU bermain. Dalam hal ini, masing-masing kota tersebut memiliki keunikan tersendiri. Di Jakarta, mereka sangat dekat segala yang mereka butuhkan untuk mensosialisasikan pikiran mereka. Adapun di Yogyakarta, kiprah anak muda NU memang cukup terasa dalam kancah intelektual di kota Gudeg ini. Hal tersebut tampak dari beberapa LSM dan penerbitan yang dimotori oleh anak muda NU. Sementara di Surabaya, mereka berkiprah seperti di "rumah sendiri," sebab di kawasan ini, merupakan kantong utama NU.

Dalam hal ini, pemikiran mereka tentu saja sangat dipengaruhi oleh sosio-kultural yang berkembang di sekitarnya. Di samping itu, faktor geneologi juga ikut memainkan peran yang cukup signifikan. Saya berargumen bahwa ada beberapa faktor yang cukup mendasar dalam jaringan geneologi pemikiran mereka. Pertama, pesantren sebagai pusat denyut nadi tradisi intelektual NU; Kedua, kinerja LSM; Ketiga, jaringan keilmuan yang dibangun dari Mesir; Keempat, IAIN sebagai tempat yang tidak memberikan nilai kepuasan intelektual bagi mereka, sehingga mencari altematif kegiatan lainnya yang menunjang intelektual mereka; Kelima, faktor pemikiran para pemikir Islam kontemporer yang cenderung radikal dan kekiri-kirian; Keenam, hubungan dengan para indonesianis luar negeri; Ketujuh, figur sentral Gus Dur sebagai pelindung dalam menuangkan ideide liberal mereka. Lebih lanjut, saya tertarik untuk mengupas satu persatu argumen tersebut dengan melihat dari karya-karya yang telah dilakukan oleh anak muda NU ini.

${ }^{3} \mathrm{Di}$ antara mereka adalah Ulil Abshar-Abdalla, Ahmad Baso, Zuhairi Misrawi, Khamami Zada, Marzuki Wahid, M. Imadun Rahmat, Hairus Salim HS, dan lain sebagainya.

${ }^{4}$ Lihat misalnya, Fauzan Saleh, 2001, Modern Trends in Islamic Theological Discourse in $20^{\text {h }}$ Century Indonesia, Leiden: Brill, 2001, hal. 285-294. 


\section{Pesantren sebagai basis intelektual}

Di Indonesia, pesantren merupakan lembaga studi Islam yang punya nilai historis terhadap gerakan sosial keagamaan. ${ }^{5}$ Karena itu, pesantren selalu menjadi "catatan pinggir" dan "catatan utama" dalam rentak pemikiran kelompok Islam tradisionalis di Indonesia. Sebagai "catatan pinggir", pesantren telah menjadi semacam faktor pelapisan intelektual. Dengan kata lain, studi Islam di pesantren merupakan salah satu dari lapis-lapis jenjang intelektual yang pada gilirannya, alumni dapat memiliki beberapa keuntungan sekaligus. Pertama, di pesantren, mereka telah menguasai tradisi klasik yang hanya dapat diperoleh melalui lembaga ini. Kechua, tempaan disiplin dan filosofi “desa kecil" akan membekas bagi santrinya ketika mereka berkiprah di tengah-tengah masyarakat umum. Ketiga, dari dunia pesantren, seorang santri telah memasuki dunia sungguhan dalam mempelajari Islam. Sebab mereka mendapatkan ilmu dari sumbernya yang asli. Hal ini berbeda dengan model studi Islam di sekolah atau pengajian yang hanya mempelajari Islam hanya untuk "escape from hell " sehingga out put nya pun adalah untuk kesalehan individu.

Adapun sebagai “catatan utama”, pesantren telah mencetak kader-kader pemikir Islam di Indonesia. Harus diakui, hampir semua pemikir Islam Indonesia merupakan jebolan pesantren atau setidaknya pernah mengalami dunia pesantren. Karena itu, para pemikir ini pun tidak pernah melupakan pesantren. Salah satu akibatnya adalah para alumni pesantren kemudian mencoba menghidupkan kembali pesantren melalui berbagai program. Lebih dari itu, hampir semua kejadian politis di Indonesia selalu dikaitkan dengan pesantren. Bahkan pejabat dan elit politik sering melirik pesantren sebagai basis massa mereka dan momen tertentu.

Dalam konteks tersebut, maka tidak keliru Abdurrahman Wahid mengatakan bahwa:

It is also indicated that the ideology of the pesantren, conceptually, socially, and politically combated colonialism in Java. Thus, the conventional assumption that Javanese santris were politically quiet because they were Ash'ari is not justified. Through the notion of "cultural resistance" inherited from the Walisongo, the pesantren tradition displayed its dynamism to flexibly absorb local and foreign elements but still to stand uniquely on Islamic principles. ${ }^{6}$

Selanjutnya, pada tahun 1990-an, anak-anak muda NU yang telah menempuh studi di pesantren mulai melakukan proses urbanisasi intelektual. Mereka yang dulunya

${ }^{5}$ Lihat Zamakhsyari Dhofir, 1994, Tradisi Pesantren: Studi tentang Pandangan Hidup Kyai, Jakarta: LP3ES; Kamaruzzaman Bustamam-Ahmad, 2002, Islam Historis: Dinamika Studi Islam di Indonesia, Yogyakarta: Galang Press, hal. 65-82.

${ }^{6}$ Abdurrahman Wahid, 2000, "Why the Pesantren In Indonesia Remains Unique and Stronger," dalam Isma-ae Alee et.al. (ed.), Islamic Siudies In Asean: Presentations of an International Seminar, (Thailand: Prince of Songkla University Pattani Campus, hal.198. 
hanya membaca kitab kuning, memakai sarung, peci, mendengar radio butut di sudutsudut kamar pondok dan makan tiga ' $t$ ' (tahu, telor dan tempe), menjadi seorang pemuda yang membaca kitab putih, memakai jeans dan gaya parlente, menyetel tv dan akrab dengan computer, dan tidur di kantor-kantor yang serba beton. Inilah yang sering disebut dengan gejala "santri kota." Sebaliknya, pada saat yang sama, kelompok pendidik lainnya, sedang melakukan proses santrinisasi, $\mathrm{NU}$ ternyata telah siap lebih dulu, dan karenanya mereka merasa tidak terlambat dalam gerakan ini.

Kelompok anak muda ini mulai melirik pemikiran Islam kontemporer yangkekirikirian. Mereka juga mulai akrab dengan teori-teori sosial yang pada gilirannya menjadi pisau analis dalam menuangkan ide-ide cerdasnya. Namun, semangat "pesantrenisme" tetap melekat dalam benak mereka. Tradisi debat merupakan hal lain yang terjadi di kalangan anak muda NU. Mereka tidak sungkan melabrak hal-hal yang sudah "mapan" termasuk dengan generasi tua sekalipun. Hal ini tentu saja menyebabkan "generasi tua" gerah dengan tingkah laku mereka. Namun, karena didukung oleh Abdurrahman Wahid (Gus Dur), pikiran mereka tetap menjalar ke tema-tema yang kadang kadang menyentak kelompok non-NU.

Hingga di sini, saya ingin mengatakan bahwa apa yang mereka peroleh di pesantren merupakan modal utama ketika turun ke realitas sosial yang sesungguhnya. Dengan kata lain, kendati komunitas NU dikenal sebagai kelompok tradisional, namun di pihak lain hal itu merupakan modal sosial-intelektual dan kekuatan bagi NU. ${ }^{8} \mathrm{Dan}$ pesantren, pada akhirnya, mempunyai kekuatannya sendiri berupa "nilai" yang tidak dimiliki oleh lembaga lain. ${ }^{9}$ Pendek kata, jaringan intelektual yang dibangun melalui pesantren telah mampu menempatkan generasi muda NU sebagai kelompok terdepan dalam memahami realitas sosial yang ada.

\section{Kinerja LSM}

Hingga kini, saya mengamati bahwa tidak sedikit generasi muda NU mendirikan. LSM yang didanai oleh funding-funding internasional. Di Jakarta, Lembaga Kajian dan Pengembangan Sumberdaya Manusia (LAKPESDAM), tampaknya menjadi "anak emas" lembaga-lembaga asing, tidak terkecuali ISI dan Yayasan Desantara. Hal serupa juga ditemui di Yogyakarta ada Lembaga Kajian Islam dan Sosial (LKiS) dan Surabaya Lembaga Studi Agama dan Demokrasi (eLSAD). Demikian juga PKASP di Mojokerto, LPIM Kediri, Salsabila di Malang, dan Sketsa di Jember. Kondisi tersebut menciptakan gairah intelektual tersendiri bagi mereka. Gaya kerja LSM yang cenderung terjun ke

${ }^{7}$ Lihat Mochamad Sodik, 2000, Gejolak Santri Kota: Aktivis Muda NU Merambah Jalan Lain, Yogyakarta: Tiara Wacana.

${ }^{8}$ Rumadi, 2000. "Jejak-jejak Liberalisme NU," Tashwirul Afkar, No.9, hal. 11.

'Ibid., hal. 12. 
lapangan, telah mempertemukan anak muda NU dengan tema-tema sosial. Untuk itu, mereka pun harus siap dengan "bersaing" dengan apa yang dilakukan oleh pendahulu mereka yaitu Gus Dur dan Masdar Mas'udi yang terlebih dahulu terlibat dalam dunia LSM.

Sementara itu, menurut pengakuan anak muda NU, Khamami Zada, salah satu alasan mengapa mereka tertarik aktif di LSM, karena anak-anak NU yang tumbuh itu mewarisi perasaan terpinggirkannya kalangan NU dari jaringan birokrasi sepanjang era Orde Baru. ${ }^{10}$ Dengan kata lain, karir di LSM merupakan jalur alternatif yang cukup menjanjikan.

Harus diakui, dalam konteks ini, kinerja LSM yang dilakukan oleh generasi muda NU telah memposisikan mereka sebagai organisasi yang diperhitungkan dalam kancah ke-LSM-an di Indonesia. Mereka mulai akrab dengan advokasi, training, seminar dan penerbitan yang sering dilakukan oleh kelompok LSM. Dengan demikian, anak muda NU pada urutannya harus memenuhi "keinginan" para donatur agar mereka banyak menyentuh persoalan sosial seperti HAM, gender, demokratisasi, dan lain sebagainya. Tanpa disadari cara kerja ini pada akhimya menyebabkan mereka lebih banyak berkutat di luar kampus, ketimbang di kampus dalam pengembaraan intelektual. Karena visi mereka terkait dengan pengembangan civil society, maka bentuk kegiatan mereka pun sering didanai oleh funding asing. Bagi mereka, perbedaan aliran dan kepercayaan agama tidak dijadikan alasan untuk meniadakan jalinan kerja sama tersebut. ${ }^{11}$

Hal di atas pada gilirannya terefleksikan dalam pemikiran mereka dimana lebih banyak mempertimbangkan nuansa konteks, ketimbang teks itu sendiri.Akibatnya, teks bagi mereka adalah konteks itu sendiri. Artinya, konteks lah yang membentuk suatu teks dan harus dipahami melalui teori-teori sosial. Dengan kata lain, pada tahap ini, anak muda NU tidak mau lagi terkungkung oleh teks-teks suci yang cenderung membelenggu tradisi intelektual Islam. Dari sudut ini, kita dapat memahami mengapa pikiran-pikiran anak muda NU cenderung radikal atau bahkan melabrak teks-teks suci yang telah disakralkan oleh umat Islam selama ini.

Hal ini juga dapat dipahami dari aktivitas ke-LSM-an Gus Dur dan Masdar pada tahun 1980-an. Mereka saat itu mulai mengakrabkan diri dengan fenomena sosial yang kadang kala tidak diatur dalam kitab-kitab fiqh klasik. Karena itu, mereka membentuk fiqh tersendiri dalam memahami fenomena sosial. Dalam hal ini, tidak begitu mengejutkan jikaUlil Cs memiliki pemikiran seperti generasi pendahulu mereka (Gus Dur dan Masdar). Karena itu, tidak mengejutkan jika ada pandangan yang mengatakan bahwa munculnya

${ }^{10}$ Arahman Ma'mun, 2003, “Anak Muda NU di Berbagai Penjuru," Panjimas, No. 17, hal. 25.

"Mochamad Sodik, 2000, Gejolak Santri Kota, hal. 52. 
LSM yang dibidani oleh aktivis muda NU itu dapat dipandang sebagai basis sosialinetelektual baru dalam jama'ah $N .^{12}$

\section{Jaringan keilmuan yang dibangun dari Mesir}

Azyumardi $\mathrm{Azra}^{13}$ dan Mona Abaza ${ }^{14}$ telah memberikan informasi kepada kita bagaimana 'jaringan keilmuan' yang dibangun di Nusantara (Indonesia) melalui koneksi intelektual Haramayn dan Mesir. Dari kawasan tersebut, ghirah intelektual di Nusantara terbangun. Dari Haramayn, misalnya, memunculkan pembaruan yang digagas oleh Nuruddin Ar-Raniry yang kemudian disebarkan oleh Yusufal-Makassari. Demikian juga, dari Mesir jaringan intelektual yang dibangun oleh alumni Kairo telah menyebabkan lahirnya pembaruan pemikiran Islam pada abad 19 di Indonesia. Harus diakui, koneksi ini ternyata masih berkembang sampai sekarang. Keinginan untuk studi Islam di Timur Tengah adalah "impian" tersendiri bagi beberapa generasi muda Islam di Indonesia, tidak terkecuali anak muda MU..$^{15}$

Dalam hal ini, anak muda NU juga mengalami hal yang serupa. Sebab, tidak sedikit anak muda NU yang tamat pesantren belajar di al-Azhar. Semangat intelektual di Mesir ternyata menyebabkan adanya transformasi intelektual dalam diri anak muda NU. Di Mesir mereka mendirikan jaringan intelektual tersendiri dengan berbagai kegiatan ilmiah. Aktvitas ini tentu saja sangat dipengaruhi oleh perkembangan pemikiran di kawasan tersebut. Menurut pengakuan salah seorang alumni mahasiswa al-Azhar, mereka memilih media massa sebagai salah satu corong gerakan, karena media massa-lah yang paling cepat dan strategis dalam mensosialisasikan ide-ide atau pemikiran ke kalangan mahasiswa di al-Azhar. Disamping itu, mereka mendirikan $s t u d y$ club sebagai alternatif untuk memecahkan kejumudan dinamika pemikiran. Lebih jauh, mereka juga menerbitkan berbagai bulletin atau jurnal sebagai media untuk membenamkan pemikiran mereka. ${ }^{16}$

Di samping itu, langgam pemikiran Islam yang berkembang di Mesir juga ikut memberikan pengaruh terhadap dialektika pemikiran anak muda NU. Harus diakui, bahwa tradisi pemikiran yang berkembang di Mesir memang tidak begitu jauh berbeda dengan Indonesia. Dengan begitu, mereka telah akrab betul dengan tradisi jadal bi

${ }^{12}$ Mochamad Sodik, 2000, Gejolak Santri Kota, hal. 53.

${ }^{13}$ Azyumardi Azra, 1994, Jaringan Ulama, Bandung: Mizan. Lihat juga Kamaruzzaman Bustamam-Ahmad, 2003, "Kontribusi Prof. DR. Azyumardi Azra dalam Studi Sejarah Sosial Islam di Asia Tenggara," (Makalah akan diterbitkan).

${ }^{14}$ Mona Abaza, 1999, Pendidikan Islam dan Pergeseran Orientasi: Studi Kasus Alumni Al-Azhar, Jakarta: LP3ES.

${ }^{15}$ Lihat misalnya, Arif Hidayat, 1999, "KMNU, Al-Azhar, dan Generasi Baru," Tashwirul Afkar, No.6, hal. 68-75.

${ }^{16}$ Arsyad Hidayat, 2000, "Mencari Islam Alternatif; Perjalanan Seorang Mahasiswa AlAzhar," Tashwirul Afkar, No.8, hal. 81-82. 
hikmah. Inipun kemudian mereka kembangkan ketika pulang ke Indonesia. Oleh sebab itu, tidak mengherankan jika justru pemikiran liberal di kalangan anak muda Islam Indonesia lebih banyak ditelurkan oleh anak muda NU yang pernah studi di al-Azhar. Dengan demikian, orientasi bahwa belajar ke Timur Tengah akan menciptakan generasi penghapal teks telah runtuh dengan melihat tradisi pemikiran yang dikembangkan oleh anak muda NU ini.

Anak muda NU yang studi Islam di Mesir ternyata mereka sangat aktif pula mengikuti trend pemikiran Islam yang berkembang di Indonesia. Tidakjarang, mereka mengundang para pemikir Islam di Indonesia untuk berceramah di negeri Nabi Musa ini. Karena itu, tidak begitu sulitbagi mereka, setelah pulangke Indonesia, langsung menceburkan diri ke dalam kancah "sungai pemikiran Islam" di negeri ini. Dengan demikian, liberalisme pemikiran yang berkembang di Mesir, ${ }^{17}$ pada gilirannya dipertemukan dengan liberalisme pemikiran anak muda NU di Indonesia. Dalam bahasa Rumadi, "belakangan anak-anak muda NU yang belajarke Timur Tengah, terutama al-Azhar Mesir, justru menampakkan gejala liberalisme yang luar biasa. ${ }^{18}$

\section{IAIN}

Sejauh ini, IAIN merupakan salah satu lembaga yang menciptakan produsen pemikiran Islam di Indonesia. Kenyataan ini tentu saja dipicu oleh kebebasan akademik yang diperoleh mahasiswa selama studi di IAIN. Mereka bebas "terbang" kemanamana mulai dari pemikiran yang paling kanan sampai ke kiri-kirian sekalipun. Secara historis, pemikir Islam kontemporer di Indonesia pun banyak dihasilkan dari IAIN. ${ }^{19}$ Karena itu, langgam pemikiran Islam di Indonesia sedikit banyak dipicu oleh tradisi intelektual yang dibangun IAIN.

Namun demikian, faktor IAIN inipun telah menyebabkan anak muda NU jenuh dengan model pembelajaran ala IAIN yang cenderung bersifat normatif-deduktif-teologis. Akhirnya, sebagai bentuk pemberontakan terhadap gejala tersebut, tidak sedikit anak NU yang mulai "loncat pagar". Mereka tidak lagi tertarik dengan pemikiran klasik Islam. Untuk itu, mereka mulai mendekatkan diri dengan "kitab-kitab putih" yang terkadang dipelajari oleh mahasiswa S-2 di perguruan tinggi umum. Mereka cenderung mempelajari pemikiran sekular, seperti Karl Marx. Max Weber, Michel Foucault, Nietzse, Sigmund Frued dan lain sebagainya. Bacaan ini memang bukan "barang baru", tetapi pergeseran

${ }^{17}$ Lihat misalnya, Zuhairi Misrawi, 2000, "Pemikiran Islam Kontemporer di Mesir: Sebuah Pergolakan dari Ekslusivisme menuju Inklusivisme," Tashwirul Afkar, No.8, hal. 4-28.

${ }^{18}$ Rumadi, 2000 “Jejak Liberalisme NU," Tashwirul Afkar, No.9, hal. 17.

${ }^{19}$ Lihat misalnya, M. Dawam Rahardjo, 1998, "Kata Pengantar: Dari Modernisme ke Pasca Modernisme," dalam Kamaruddin Hidayat, Tragedi Rajas Midas: Moralitas Agama dan Krisis Modernisme, Jakarta: Paramadina, h.xvii-xix; idem, 1999, "Kata Pengantar," dalam Edy A. Effendy, (ed.), Dekonstruksi Islam: Mazhab Ciputat, Bandung: Zaman Wacana Mulia, hal. vii-xxviii. 
ini menyebabkan dalam tingkat aksi mereka di lapangan. Akibatnya, pembebasan sebagai simbol gerakan rakyat menjadi lebih enak dipandang ketimbang simbolisme beku.

Alhasil, anak muda NU pun ikut kecipratan pemikiran di atas. Mereka mulai melalukan proses "deisme" yaitu segala yang sudah mapan dicoba dekonstruksi. Proses "deisme" ini tampak dalam tulisan di media massa dan judul buku atau jurnal.yang diterbitkan oleh anak muda NU. Hal ini tentu saja sangat berlawanan dengan tradisi klasik NU yang cenderung mengusung teks-teks kitab kuning yang menyebabkan pemikiran mereka stagnan. Atas situasi seperti itu, anak muda NU ternyata mencoba melakukan proses "deisme" dalam segala hal. Karena itu, tidak mengejutkan jika kemudian muncul isu-isu di kalangan anak muda NU seperti dekonstruksi syariah, deformalisasi syariat, menggugat fundamentalisme Islam dan lain sebagainya.

\section{Pengaruh pemikiran para Pemikir Islam kontemporer Timur Tengah ${ }^{20}$}

Harus diakui, tidak sedikit jasa anak muda NU dalam memperkenalkan pemikiran sarjana Islam kontemporer Timur Tengah. Ahmad Baso telah berjasa, setidaknya, dalam mensosialisasikan pikiran Muhammad Abed Al-Jabiri. ${ }^{21}$ Demikian juga, LKiS telah menyentak pikiran umat Islam Indonesia dengan menerbitkan buku Abdullahi An-Naim, Mohammad Arkoun, Nasr Hamid Abu Zayd, Ali Harb, dan Muhammad Syahrur. Zuhairi Misrawi secara rajin mengutip pandangan-pandangan pemikir Islam kontemporer Timur Tengah dalam beberapa tulisannya. ${ }^{22}$ Tiga anak muda NU ini memang bukan sendiri dalam mensosialisasikan pemikiran tokoh Islam kontemporer Timur Tengah. Tampaknya, mereka selalu terdepan dalam melakukan perombakan pemikiran Islam melalui penerjemahan dan penerbitan karya-karya tokoh tersebut.

Pada dataran berikutnya, tidak sedikit pikiran tokoh di atas mempengaruhi gaya berpikir anak muda NU yang cenderung liberal. Merekà secara telegrafik mulai sering mengutip dan mensyarah pemikiran tersebut dalam menganalisis situasi sosial-politikagama-budaya di Indonesia. Dalam hal ini, tidak dapat dipungkiri dari tulisan anak muda

${ }^{20}$ Sebagai pengantar untuk pemikiran Timur Tengah dalam konteks kekinian, baca A. Luthfi Assyaukanie, 1998, "Tipologi dan Wacana Pemikiran Arab Kontemporer," Paramadina, Vol.I, No.1, hal. 58-95; Ali Harb, 2003, Kritik Nalar Al-Qur'an, Yogyakarta: LKiS.

${ }^{21}$ Ahmad Baso, 2000, "Kata Pengantar: Posmodernisme Sebagai Kritik Islam: Kontribusi Metodologis "Kritik Nalar" Muhammad Abed al-Jabiri," dalam Muhammad Abed Al-Jabiri, Post Tradisionalisme Islam, Yogyakarta: LKiS, h.ix-liv; idem, 2001, "Neo-Modernisme Islam Versus Post-Tradisionalisme Islam," Tashwirul Afkar, No.10, h.24-46; idem, 1999, "Problem Islam dan Politik Perspektif "Kritik Nalar Politik" Muhammad Abed al-Jabiri," Tashwirul Afkar, No.4, hal. 2939.

${ }^{22}$ Lihat misalnya, Zuhairi Misrawi, 200i, "Dari Tradisionalisme Menuju PostTradisionalisme Islam: Geliat Pemikiran Baru Islam Arab," Tashwirul Afkar, No.10, hal. 47-61. 
NU sering menghiasi surat kabar dan jurnal melalui kerangka yang telah dibangun oleh para pemikir Timur Tengah. Anak muda NU sangat piawai dalam menghasilkan konsepkonsep pemberdayaan umat yang berbasiskan pada budaya lokal.

Dari sini mereka mulai membenturkan aspek pemikiran sarjana Islam Timur Tengah seperti Nashr Hamid Zayd melalui konsep teks. Atau, post-tradisionalisme yang dipinjam dari Mohammad Abed al-Jabiri, dalam konteks kekinian di Indonesia. Paling tidak, corak pemikiran anak muda NU juga akan tetap berpijak dari tradisi teks yang dikembangkan oleh para pemikir Islam kontemporer Timur Tengah.

\section{Hubungan dengan para indonesianis}

Dewasa ini, saya melihat para indonesianis telah berjasa dalam membentuk pemikiran anak muda NU. Sebab, dari mereka anak muda NU memperoleh dua hal sekaligus yaitu teori dan metodologis. Dari aspek teori, anak muda NU langsung belajar dari sumber pertama yaitu para sarjana yang memang ahli dalam bidangnya. Biasanya, para indonesianis tidak ragu-ragu untuk datang ke kantong-kantong anak muda NU untuk mensosialisasikan pikiran mereka. Disamping itu, aspek metodologis, anak muda NU memang dilibatkan secara aktif oleh para indonesianis dalam melakukan penelitian lapangan.

Mereka sangat akrab dengan para indonesianis yang pernah meneliti NU. Untuk sekedar menyebut nama, Martin van Bruinessen, Robert W. Hefner, Lance Castles, Herbet Feith, Clifford Geertz, R. William Liddle, Greg Barton, Greg Fealy, Andree Feillard, Sidney Jones, dan Robin Bush adalah sebagian dari peneliti luar negeri yang mengkaji NU. ${ }^{23}$ Dari para sarjana tersebut, anak muda NU dapat beberapa percikan

${ }^{23}$ Baca beberapa karya berikut: Martin van Bruinessen, 1999, NU: Tradisi, Relasi-relasi Kuasa, Pencarian Wacana Baru, Yogyakarta: LKiS; idem, 2002, "Kembali ke Situbondo? Sikap NU terhadap Kepresidenan Gus Dur," Gerbang, Vol.V No.12, hal. 4-28; idem, 2003, "Islam Lokal dan Islam Global di Indonesia," Tashwirul Afkar, No.14, hal. 68-85; R. William Liddle, 1997, Islam, Politik dan Modernisasi, Jakarta: Sinar Harapan; idem, 1992, Partisipasi \& Partai Politik: Indonesia Pada Awal Orde Baru, Jakarta: Grafiti; Greg Barton, 1999, Gagasan Islam Liberal di Indonesia, Jakarta: Paramadina; idem, 2002, Abdurrahman Wahid Muslim Democrat, Indonesian President: A view from the Inside, Sydney: UNSW Press; idem, 1999, "Memahami Abdurrahman Wahid," dalam Abdurrahman Wahid, Prisma Pemikiran Gus Dur, Yogyakarta: LKiS; Greg Barton, 2002, "Kata Pengantar: Belajar dari Kepresidenan Wahid," dalam Khamami Zada (ed.), 2002, Neraca Gus Dur di Panggung Kekuasaan, Jakarta: LAKPESDAM, hal. xiii-xvii; idem dan Andree Feillard, 1999, 'Nahdlatul Ulama, Abdurrahman Wahid and Reformation: What Does NU's November 1997 National Gathering Tells Us?," Studia Islamika, Vol.6, No.1, hal. 1-40; Robert W. Hefner, 2000, Civil Islam: Muslims and Democratizations in Indonesia, Princeton: Princeton University Press; idem, 2000, Islam Pasar Keadilan: Artikulasi Lokal, Kapitalisme, dan Demokrasi, Yogyakarta: LKiS; Fred Inglis, 2000, Clifford Geertz: Culture, Custom and Ethics, Cambridge: Polity Press; Andree Feillard, 1999, NU Vis-á-vis Negara: Pencarian Isi, Bentuk dan Makna, Yogyakarta: LKiS; Greg Fealy, 2003, Ijtihad Politik Ulama: Sejarah NU 1952-1967, Yogyakarta: LKiS; idem, 1994, “"Rowing in a 
pemikiran Barat. Oleh karena itu, tradisi riset di kalangan anak muda NU pun menjadi mengental. Mereka sangat hafal bagaimana melakukan penelitian sosial keagamaan. $\mathrm{Di}$ samping itu, anak muda NU juga sangat rajin menerjemahkan karya-karya indonesianis ke dalam bahasa Indonesia, baik yang diterbitkan oleh lembaga anak muda NU atau lembaga lainnya.

Lebih jauh lagi, teori-teori yang dikembangkan oleh para indonesianis tersebut mulai diadopsi oleh anak muda NU dalam memahami keberagamaan. Gejala ini dapat ditemui dalam setiap tulisan anak muda NU, seperti Ulil misalnya. Ketika membahas tentang pribumisasi Islam di Indoensia, Ulil mengutip model "antropologi konversi" yang dikembangkan oleh Robert W. Hefner. ${ }^{24}$ Model serupa juga diadopsi oleh Zuhairi Misrawi ketika menjelaskan konsep "teologi antroposentrisme."25 Dengan kata lain, pikiran para indonesianis ini dicoba bumikan oleh anak muda NU melalui berbagai tulisan mereka.

Kebiasaan para indonesianis yang mengkaji NU juga telah menyebabkan anak muda NU terbiasa untuk melihat sisi keberagamaan masyarakat Indonesia dari konteks. Hal tersebut tentu saja sering bertabrakan dengan model pemikiran kalangan NU yang lebih melihat teks-teks dalam menyelesaikan suatu persoalan kekinian. Namun, hal tersebut belakangan sedikit berubah dengan adanya pembaruan yang dibawa oleh Gus Dur dan Masdar, ketika terjadi perdebatan dalam beberapa kali muktamar NU. ${ }^{26}$ Anak muda NU sadar betul bahwa fenomena keagamaan lebih berharga daripada isi agama itu sendiri. Sebab itu, mereka menolak usaha untuk menformalkan Islam dalam bentuk gerakan, negara, hukum, dan isu-isu kekinian. Pandangan ini tentu saja sangat berdekatan dengan "keinginan" para indonesianis yang ingin melihat NU sebagai organisasi modern.

Typhoon": Nahdlatul Ulama and the Decline of Parlimentary Demovracy," dalam David Bourchier dan John Legge (ed.), Democracy in Indonesia 1950a and 1990s, Clyaton: Centre of Souteast Asian Studies, Monash University, hal. 88-98; idem, 1996, "Wahab Chasbullah, Traditionalism and the Political Development of Nahdlatul Ulama," dalam Greg Barton dan Greg Fealy (ed.), Nahdlatul Ulama, Traditinal Islam and Modernity in Indonesia, Clyaton: Centre of Souteast Asian Studies, Monash University, hal. 1-41; Robin Bush, 2000, "Redefining "Political Islam" in Indonesia: Nahdlatul Ulama and Khittah '26," Studia Islamika, Vol.7, No.2, hal .61-86; idem, 2003, "Anak-anak Muda, Masih di Sisi Tradisionalis," No. 16, Oktober, hal. 32-33; Remy Madinier dan Andree Feillard, 1999, "At the Sources of Indonesian Political Islam's Failure: The Split between the Nahdlatul Ulama and the Masyumi in Retrospect," Studia Islamika, Vol.6, No.1, hal.1-38; Sidney Jones, 1984, "The Contraction and Expansion of the 'Umat' and the Role of Nahdlatul Ulama in Indonesia," Indonesia, No.84, hal. 1-20.

${ }^{24}$ Ulil Abshar Abdalla, 2003, "Menimbang Islam Pribumi," Tashwirul Afkar, No.14, hal.129.

${ }^{25}$ Zuhairi Misrawi, 2002, "Post Tradisionalisme Islam: Dari Teologi Teosentrisme menuju Teologi Antroposentrisme," Millah, Vol.II, No.1, hal. 22-36.

${ }^{26}$ Lihat misalnya, Greg Barton dan Andree Feillard, 1999, Nahdlatul Ulama, Abdurrahman Wahid and Reformation, hal.16-25. 


\section{Figur sentral Gus Dur}

Hingga detik ini, tidak sedikit para pengamat yang mengatakan bahwa Gus Dur merupakan "bapak intelektual" bagi anak muda NU. Figur Gus Dur telah menyelinap dalam pemikiran anak muda NU. Hampir dapat dikatakan bahwa keenam faktor sebelumnya telah dimiliki oleh Gus Dur. Tokoh ini memang telah bertahun-tahun terlibat dalam dunia pesantren. ${ }^{27}$ Tidak jarang, pikiran-pikirannya memang selalu menempatkan pesantren sebagai sub-kultur. Tidak hanya disitu, untuk memberdayakan pesantren, dia terlibat dengan dunia LSM melalui berbagai program pemberdayaan lembaga studi ini. Gus Dur juga pernah belajar di Mesir, yang karenanya, dia paham betul bagaimana transformasi pemikiran Islam yang berkembang di Timur Tengah. Di samping itu, Gus Dus juga sangat dekat para indonesianis luar negeri. Tidak jarang, dia sering menjadi tempat konsultasi mahasiswa S-3 luar negeri terhadap fenomena keberagamaan masyarakat Indonesia. Ringkasnya, dia menjadi “juru bicara" Indonesia terhadap para peneliti asing. Karena itu, lengkap sudah figur Gus Dur untuk dicontoh oleh anak muda NU.

Salah satu sifat Gus Dur yang dicontoh oleh anak muda NU adalah tradisi menentang arus. Harus diakui bahwa Gus Dur memang sosok yang selalu mengundang kontroversial di Indonesia. Kebiasaan ini, tentu saja tidak membuat Gus Dur takut, dan malah cucu pendiri NU ini semakin radikal, jika ditentang pikirannya. Sifat ini kemudian begitu mengental dalam jiwa anak muda NU. Mereka tidak takut untuk mengusung isuisu yang menentang arus. Dalam beberapa hal tertentu, mereka juga meneruskan beberapa

${ }^{27}$ Tentang Abdurrahman Wahid baca beberapa karya berikut: Greg Barton 1995, "NewModernism: A Vital Synthesis of Traditionalist and Modernist Islamic Thought in Indonesia", Studia Islamika. Vol.2, No.3, hal. 45-63; idem 1997, "Indonesia's Nurcholish Madjid and Abdurrahman Wahid as Intellectual ulama: the meeting of Islamic traditionalism and Modernism in Neo-Modernist thought", Islam and Christian-Muslim, Vol. 8, No.3, h. 337-342; idem (1999), Gagasan Islam Liberal, hal. 325-429; idem 1999, Memahami Abdurrahman Wahid, h.xx-xlv; Ma'mun Murod Al-Brebesy 1999, Menyingkap Pemikiran Politik Gus Dur \& Amien Rais, Jakarta: Raja Grafindo Persada, hal. 85-117; Dedy Djamaluddin dan Idi Subandy Ibrahim 1998, Zaman Baru Islam Indonesia: Pemikiran \& Aksi Politik Abdurrahman Wahid, M. Amien Rais, Nurcholish Madjid, dan Jalaluddin Rakhmat, Bandung: Zaman Wacana Mulya, hal. 77-99; Umaruddin Masdar (1998), Membaca Pikiran Gus Dur dan Amien Rais tentang Demokrasi, c.2. Yogyakarta: Pustaka Pelajar, hal.117-130; Niels Mulder 2000, Indonesia Images: the Culture of the Public World, Yogyakarta: Kanisius, hal.120-124; Douglas E. Ramage 1995, Politics in Indonesia: Democracy, Islam and the Ideology of Tolerance, London: Routledge, hal. 49-55; idem 1997, "Pemahaman Abdurrahman Wahid tentang Pancasila dan Penerapannya dalam Era Paska Asas Tunggal", dalam Ellyasa KH. Dharwis (ed), Gus Dur, NU dan Masyarakat Sipil, Yogyakarta: LKiS, hal. 101-121; Arief Subhan (1995), "Abdurrahman Wahid", Ulumul Qur'an, No.3, Vol.VI, hal. 33-34; Paridah S. Samad (2001), Gus Dur: A Peculiar Leader in Indonesia's Political Agony, Malaysia: Penerbitan Salafi; Mujamil Qomar 2002, NU "Liberal": Dari Tradisionalisme Ahlussunnah ke Universalisme Islam, Bandung: Mizan, hal.164-177. 
pikiran Gus Dur. Dengan demikian, dapat disimpulkan bahwa Gus Durmemang menjadi "nabinya" anak muda NU.

Mereka terkadang menjadi pembela setia Gus Dur, kendati dengan bahasa yang kritis. Salah satunya adalah seperti yang dilakukan oleh Ulil ketika membeberkan bagaimana NU dipecundangi selama kepemimpinan Gus Dur menjadi Presiden Republik Indonesia. Para anak muda NU melakukan semacam evaluasi terhadap kepemimpinan Gus Dur, Mereka menerbitkan buku Neraca Gus Dur di Panggung Kekuasaan. ${ }^{28}$ Dalam buku tersebut, intelektual muda NU dengan gaya bertutur mereka, "menempatkan" Gus Dur sebagai sejarah bagi NU dan Nahdiyyin. Hal ini mengindikasikan bahwa anak muda NU memang punya misi dan visi bagaimana menjadikan NU sebagai organisasi terdepan dalam kancah politik Indonesia, melalui ide-ide cerdas Gus Dur.

Akhirnya, kita telah melihat bagaimana geneologi pemikiran anak muda NU dalam kancah intelektual Islam di Indonesia. Paling tidak, esei ini telah menunjukkan bahwa pemikiran anak muda NU tidak berdiri sendiri atau genuine. Mereka masih dipengaruhi oleh situasi sosio-budaya yang terjadi disekitarnya. Namun, mereka cukup cerdas ketika tujuh faktor tersebut dijadikan sebagai modal bagi pengembangan pemikiran mereka sendiri. Karena itu, sikap inklusifisme mereka ternyata telah membuat mereka semakin "liar"dan "liberal".

Tampaknya, untukmengambarkan geneologi pemikiran mereka, diagram berikut menunjukkan bagaimana hubungan tersebut.

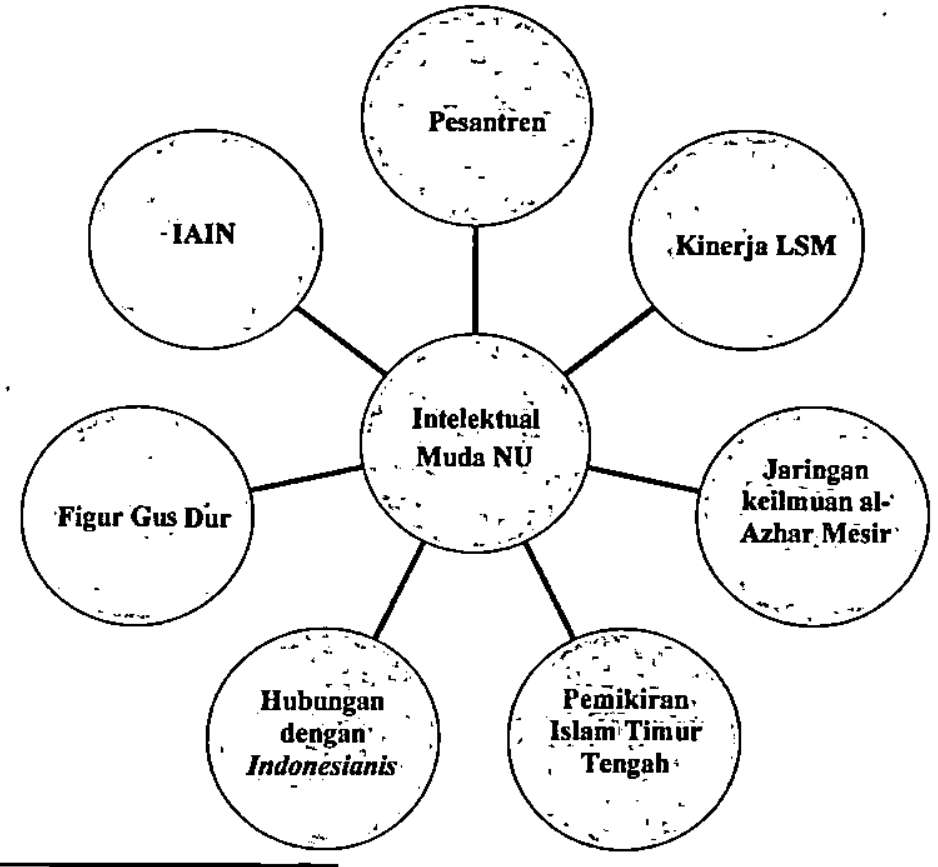

${ }^{28}$ Lihat Khamami Zada (ed.), 2002, Neraca Gus Dur di Panggung Kekuasaan, Jakarta: LAKPESDAM: 
Tujuh faktor tersebut temyata tidak berdiri sendiri. Dengan kata lain, ada hubungan satu sama lain yang tidak dapat diabaikan. Inilah yang menjadi modal bagi anak muda NU untuk bebas berkarya dalam kancah intelektualita Islam di Indonesia. Mereka mampu memanfaatkan tujuh faktor tersebut secara bersamaan. Jika dilihat dengan kelompok pemikiran Islam lainnya, maka sangat sulit ditemukan ada faktor yang mempengaruhi mereka seperti yang dialami oleh anak muda NU.

\section{Penutup}

Akhirnya, masing-masing faktor tersebut saling terkait kelindan alias tidak dapat dipisahkan. Keberadaan pesantren, LSM, jaringan keilmuan al-Azhar, pemikir Timur Tengah, indonesianis, IAIN, dan Gus Dur merupakan "jam tangan" anak muda NU dalam keharian mereka. Jika kita ingin mengambarkan kekuatan anak NU, maka "jam tangan" ini berdetak satu nafas dengan ritme intelektual anak muda NU. Karenanya, tidak berlebihan jika dikatakan bahwa, dibandingkan dengan generasi muda Islam lainnya di Indonesia, ${ }^{29}$ anak muda NU telah memiliki modal yang cukup untuk menjadi pemikir Islam di Indonesia. Untuk sekedar menyebut nama, Harun Nasution, Abdurrahman Wahid, Nurcholish Madjid, Djohan Effendi, adalah mereka yang telah "memanfaatkan" tujuh faktor di atas.

\section{DAFTAR PUSTAKA}

Abaza, Mona, 1999, Pendidikan Islam dan Pergeseran Orientasi: Studi Kasus Alumni Al-Azhar, Jakarta: LP3ES.

Abdalla, Ulil Abshar, 2003, "Menimbang Islam Pribumi," Tashwirul Afkar, No.14.

Ahmad, Kamaruzzaman Bustamam, 2002, Islam Historis: Dinamika Studi Islam di Indonesia, Yogyakarta: Galang Press.

Alee, Isma-ae, et.al. (ed.), Islamic Studies In Asean: Presentations of an International Seminar, (Thailand: Prince of Songkla University Pattani Campus.

Assyaukanie, A. Luthfi, 1998, "Tipologi dan Wacana Pemikiran Arab Kontemporer," Paramadina, Vol.I, No.1.

Azra, Azyumardi, 1994, Jaringan Ulama, Bandung: Mizan. 
Barton, Greg dan Andree Feillard, 1999, "Nahdlatul Ulama, Abdurrahman Wahid and Reformation: What Does NU's November 1997 National Gathering Tells Us?," Studia Islamika, Vol.6, No.1.

Baso,Ahmad, 2000, "Kata Pengantar: Posmodernisme Sebagai Kritik Islam: Kontribusi Metodologis "Kritik Nalar" Muhammad Abed al-Jabiri," dalam Muhammad Abed Al-Jabiri, Post Tradisionalisme Islam, Yogyakarta: LKiS.

------, 1999, "Problem Islam dan Politik Perspektif"Kritik Nalar Politik" Muhammad Abed al-Jabiri," Tashwirul Afkar, No.4.

-_-_, 2001, "Neo-Modemisme Islam Versus Post-Tradisionalisme Islam," Tashwirul Afkar, No.10.

Damanik, Ali Said, 2002, Fenomena Partai Keadilan: Transformasi 20 Tahun Gerakan Tarbiyah di Indonesia, Bandung: Teraju.

Dhofir, Zamakhsyari, 1994, Tradisi Pesantren: Studi tentang Pandangan Hidup Kyai, Jakarta:LP3ES.

Feillard, Andree, 1999, NU Vis-à-vis Negara: Pencarian Isi, Bentuk dan Makna, Yogyakarta: LKiS.

Harb, Ali, 2003, KritikNalar Al-Qur'an, Yogyakarta: LKiS.

Hidayat, Arif, 1999, “KMNU, Al-Azhar, dan Generasi Baru,” Tashwirul Afkar, No.6.

Hidayat, Arsyad, 2000, "Mencari Islam Alternatif; Perjalanan Seorang Mahasiswa AlAzhar," Tashwirul Afkar, No.8.

Kraine, Richard G, 2000, "The Role of Islamic Student Groups in the Reformasi Struggle: KAMMI (Kesatuan Aksi Mahasiswa Muslim Indonesia), “ Studia Islamika, Vol.7, No.1.

Ma'mun, Arahman, 2003, “Anak Muda NU di Berbagai Penjuru,” Panjimas, No. 17.

Misrawi, Zuhairi, 2000, "Pemikiran Islam Kontemporer di Mesir: Sebuah Pergolakan dari Ekslusivisme menuju Inklusivisme," Tashwirul Afkar, No. 8. 
2001, "Dari Tradisionalisme Menuju Post-Tradisionalisme Islam: Geliat Pemikiran Baru Islam Arab," Tashwirul Afkar, No.10.

-----, 2002, "Post Tradisionalisme Islam: Dari Teologi Teosentrisme menuju Teologi Antroposentrisme," Millah, Vol.II, No.1.

Rahardjo, M. Dawam, 1998, "Kata Pengantar: Dari Modernisme ke Pasca Modernisme," dalam Kamaruddin Hidayat, Tragedi Rajas Midas: Moralitas Agama dan Krisis Modernisme, Jakarta: Paramadina.

------, 1999, "Kata Pengantar," dalam Edy A. Effendy, (ed.), Dekonstruksi Islam: Mazhab Ciputat, Bandung: Zaman Wacana Mulia.

Rumadi, 2000 “Jejak Liberalisme NU," Tashwirul Afkar, No.9.

Saleh, Fauzan, 2001, Modern Trends in Islamic Theological Discourse in $20^{\text {th }}$ Century Indonesia, Leiden: Brill, 2001.

Sodik, Mochamad, 2000, Gejolak Santri Kota: Aktivis Muda NU Merambah Jalan Lain, Yogyakarta: Tiara Wacana.

Ulum, Bahrul, "Bodohnya NU" apa "NUDibodohi"?, Yogyakarta: Ar-Ruzz.

Zada, Khamami, (ed.), 2002, Neraca Gus Dur di Panggung Kekuasaan, Jakarta: LAKPESDAM. 